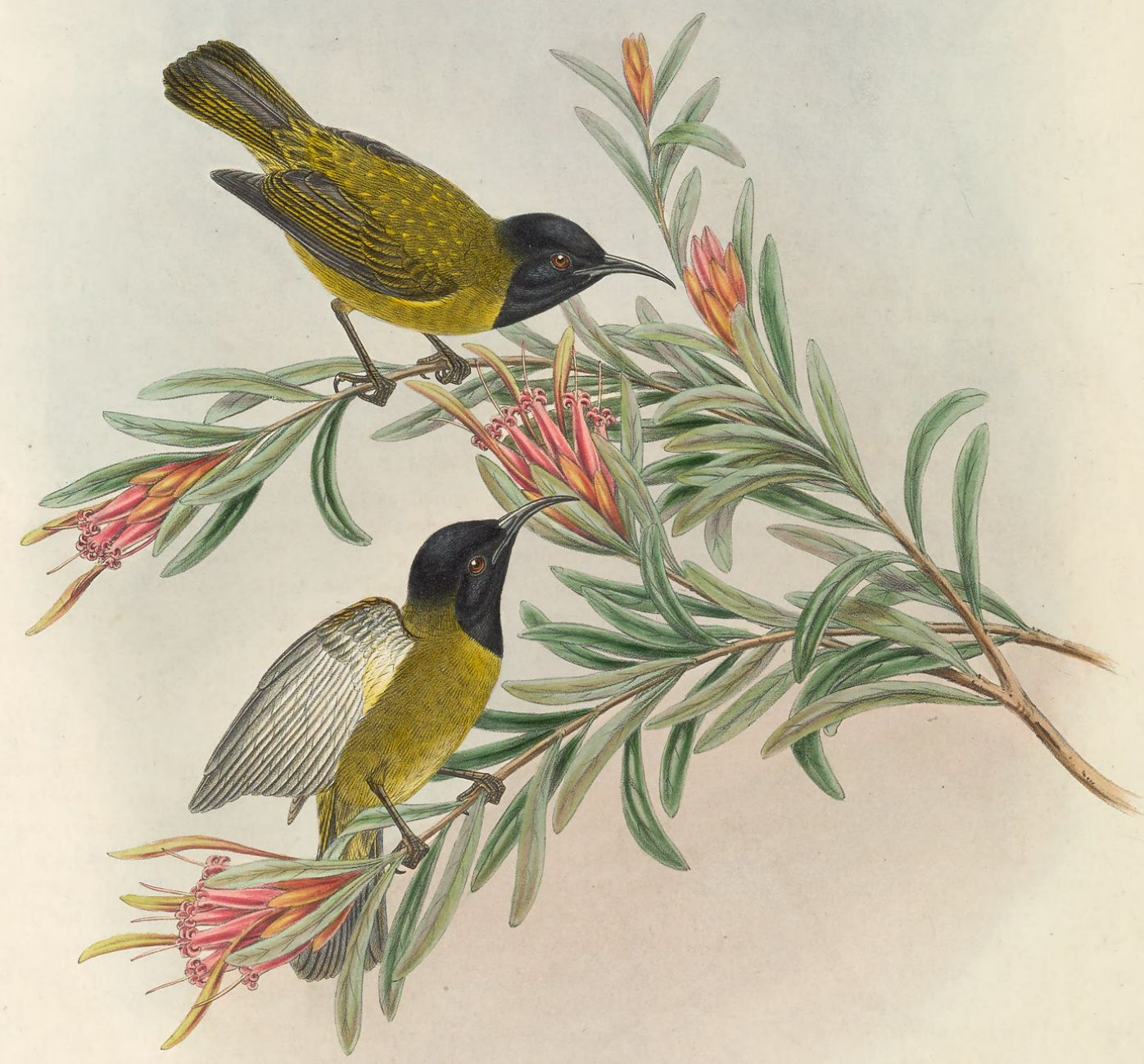




\section{MYZOMELA MELANOCEPHALA.}

\section{Black-headed Honey-sucker.}

Cinnyris (?) dubia, Ramsay (nec Bechst.), Proc. Linn. Soc. New South Wales, iv. p. 83 (1879). - Reichen. J. f. O. 1879, p. 430.-Salvad. Ibis, 1880, p. 129.

Cinnyris melanocephalus, Ramsay, Nature, 1879, p. 125.-Reichen. t. c. p. 101.

Hermotimia melanocephala, Layard, Ibis, 1880, p. 306.

Cyrtostomus melanocephalus, Salvad. Ann. Mus. Civic. Genov. xvi. p. 66 (1880).-Id. Orn. Papuasia, etc. ii. p. 269 (1881).

So peculiar is the coloration of this bird that it is scarcely surprising that some difficulty should have been experienced in finding its natural position. Mr. Ramsay doubted whether it was a true Sun-bird and called it Cinnyris? dubia, and he afterwards changed the specific name to melanocephala. He also expressed an opinion that the species might belong to the family Meliphagidee; but Count Salvadori considers it to be a true Sun-bird and has placed it in the subgenus Cyrtostomus.

On receiving the type specimen from Mr. Ramsay, we showed it to Captain Shelley, who has written such an excellent 'Monograph' of the Nectariniide, and, after careful consultation, we both agreed that it is in all probability a Meliphagine bird. We say this with all caution, as the question is a difficult one; but we notice that in Sun-birds the nostril is rounded off anteriorly, whereas in the Meliphagidae the anterior edge of the nostril vanishes gradually into the upper mandible, and this character is apparently accompanied by the brush tongue. We shall therefore expect to find that the present species has the last-named peculiarity.

In plumage this bird is not unlike some African Sun-birds, and again resembles some of the Spider-hunters (Arachnothera). In the genus Myzomela it is singularly out of place as regards it colouring, but appears to belong structurally to this genus.

The following description is taken from the typical specimen, which came from Savo in the Solomon Archipelago, and has been lent to us by Mr. E. P. Ramsay :-

Adult male. General colour above olive-yellow, with a slight appearance of brighter yellow on the mantle; upper tail-coverts dusky brown, edged with the same olive-yellow as the back; wing-coverts and quills dusky brown, narrowly edged with olive-yellow, brighter on the primaries ; bastard wing and primary-coverts uniform blackish brown; tail-feathers black, with narrow margins of olive-yellow; crown of head as far as the occiput glossy black; the nape and the sides of the hinder crown olive-yellow, but duller and rather greener than the back; lores, feathers above and behind the eye, cheeks, ear-coverts, sides of face, and throat black like the head, with a slight metallic gloss; remainder of under surface of body dull olive-yellowish, clearer olive-yellow on the fore neck, chest, and sides of neck; breast-feathers mixed with ashy, the bases being of this colour; under tail-coverts ashy brown, edged with olive-yellow; axillary tufts pale olive-yellow, with white bases; under wing-coverts white, those near the edge of the wing blackish, edged with oliveyellow; quills dusky blackish below, white along the edge of the inner web. Total length $4 \cdot 5$ inches, culmen $0 \cdot 85$, wing $2 \cdot 6$, tail $1 \cdot 9$, tarsus $0 \cdot 7$.

Another specimen, apparently younger, has a pale reddish tint on the lower back and rump, as well as on the margin of the wing-coverts, the thighs and under tail-coverts being likewise washed with this colour ; the black on the head and throat is also less clearly defined. Total length $4 \cdot 2$ inches, wing $2 \cdot 5$, tail $1 \cdot 65$, tarsus $0 \cdot 7$.

The figures in the Plate are drawn of the size of life, and represent the adult male, lent to me by Mr. Ramsay, in two positions. 


\section{$2 \mathrm{BHL}$ Biodiversity Heritage Library}

Gould, John and Sharpe, Richard Bowdler. 1884. "Myzomela melanocephala, Black-headed Honey-sucker [PI. 66]." The birds of New Guinea and the adjacent Papuan islands : including many new species recently discovered in Australia 3(XVII), -. https://doi.org/10.5962/p.322779.

View This Item Online: https://www.biodiversitylibrary.org/item/229963

DOI: https://doi.org/10.5962/p.322779

Permalink: https://www.biodiversitylibrary.org/partpdf/322779

\section{Holding Institution}

Smithsonian Libraries

\section{Sponsored by}

Biodiversity Heritage Library

\section{Copyright \& Reuse}

Copyright Status: Public domain. The BHL considers that this work is no longer under copyright protection.

This document was created from content at the Biodiversity Heritage Library, the world's largest open access digital library for biodiversity literature and archives. Visit BHL at https://www.biodiversitylibrary.org. 